\title{
Developing Sustainability Principles at Lithuanian Universities: An Interdisciplinary Approach
}

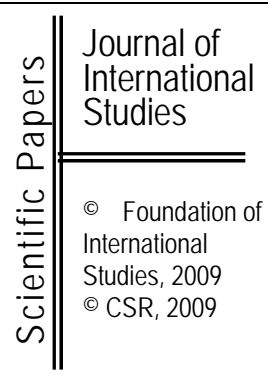

Prof. Habil. Dr. Dainora Grundey

Kannas Faculty of Humanities, Vilnius University

Muitines g. 8, 44280 Kaunas, Lithuania

Tel. +37037425 462, fax: + 37037423222

mokslo.prodek.anas@,vuk.hf.lt;

dainora.grundey@,vuk.hf.lt

\begin{abstract}
The article presents the concept of sustainability in the interdisciplinary (economic, social, ecological and institutional) context by adapting sustainability principles in the education system and presenting some evidence from Lithuanian universities from the survey, conducted in 2007-2008. The students and university lecturers of four Lithuanian universities (Vilnius University, Kaunas University of Technology, Šiauliai University and Klaipeda University) were surveyed in order to define the impact of sustainability paradigm and principles as imbedded in the daily life of a university, study curriculum and university governance.
\end{abstract}

Keywords: sustainable development, education, university governance, interdisciplinary approach, Lithuania.

JEL classification: I21, Q56, P2.

\section{Introduction}

In the process of sociological transformation towards sustainability, public institutions and especially state universities play a critical role. The present model of our society production consumption is not sustainable. The surrounding environment provides us with the obvious evidence of that. We face climate changes, decreasing of biological variety and growing global migration to the wealthy regions (Calder and Clugston, 2002). If consumption of resources continues without any limitations we will jeopardize welfare of future generations and satisfaction of their needs by wasting our natural resources. Research conducted by foreign universities support the assumption that understanding and implementation of sustainability concept in high schools require deeper and wider studies, especially from an interdisciplinary approach.

The present paper is structured as follows. The concept of sustainability has a narrower and broader meaning. Using the term of sustainability we can talk about building a sustainable global society, therefore, Chapter One presents the concept of sustainability and analyzes how sustainability principle is implemented in education system, after all universities today must assume the task of improving and perfecting the educational system in a way that will stimulate a new mentality in people of the $21^{\text {st }}$ century.

Chapter Two defines the interdisciplinary character of university studies in the 
meaning of study curriculum and study programmes, presenting the experience of Vilnius University Kaunas Faculty of Humanities, Lithuania. Chapter Three covers the findings from the national survey in Lithuania on adapting sustainability principles in university governance and some implications on study curricula as well.

Methods applied. This paper was prepared through systematic scientific literature analysis, general and logical analysis and by using methods of comparison and generalization.

\section{Sustainability Paradigm and its Application to Higher Education}

Human needs include occupation, education and learning, health care, possibility to use healthy natural environment, positive regional identity, accountable and generally elected management and even more (Viederman, 2003). This is an immediate necessity that requires for institutional and financial responsibilities. It is necessary to act and consume in compliance with sustainability principles.

Sustainability concept is important and relevant because it requires integrating opinions of different people, different business philosophies and scientific fields. Therefore, sustainability is an oft discussed and oft mentioned word. Immense work has been accomplished on why we need to be sustainable and how we could work towards it. And since it is a relatively new concept, there is more than one definition of it, and at least as many prescribed ways of achieving it. Many different definitions of sustainability exist.

Today there are over 60 definitions of sustainability, but the idea contains at least one of the following important components: concern with the long-term health of the environment; apprehension about the welfare of future generations; condemnation of rapid population growth and awareness over the possibility to maintain economic growth in the face of resource scarcity (Kooten and Bulte, 2000; Grundey et al, 2007). The term of sustainable development has been questioned because it emphasises economic growth. It is understood to consist of ever-increasing economic growth in terms of real incomes and output. It is in accordance with the Pareto-principle that is an important background assumption of social sustainability and social policy.

Universities are without dispute among the most sustainable organisations, if "sustainable" is understood as being merely long-lasting. "One study 'identified only sixty-six organizations or institutions that have been in continuous existence in Europe since the Reformation of the seventeenth century"': 62 of them were universities!" (Weick, 1976). It might sound surprising, but much of this durability might be attributable to a characteristic of expert organisation that makes it so hard to manage them as expert organisations they are, in the academic part, „loosely coupled systems“ (Weick, 1976) that are self-organising, not causing high costs of coordination. Their duty to contribute to a sustainable development of a globalised society is undisputed, however, getting more specific, different ideas as to what are the main fields of action still exists.

To adopt sustainability principles at the core of all human activities will require some fundamental changes, many of which will be very difficult technically, culturally and politically (Grundey, 2005). Universities as centres of innovation and learning should be at the forefront of this development. Such re-orientation of mission in higher education (HE) would necessarily involve a significant a) re-assessment of the curriculum, b) re-focusing of organisational structures and c) auditing and re-aligning the management and pedagogic systems (Grundey et al, 2007).

Sustainable curricula cannot be divorced from sustainable institutions. The sustainability curriculum should not centre solely on discipline focused transfers of information; its educational impact resides in stimulating interactive (student-centred) and collaborative learning processes across the university. Although there is a wide-ranging 
debate on the nature of sustainable university education, abroad consensus has emerged for three main learning outcomes. These are articulated by Rowe (2002) as:

- increased caring about the future of society and notions of 'intergenerational equality' and justice between generations;

- empowerment of students and a heightened belief that they, themselves, can make a difference;

- an increased personal willingness and commitment to participate in solving societal and environmental problems.

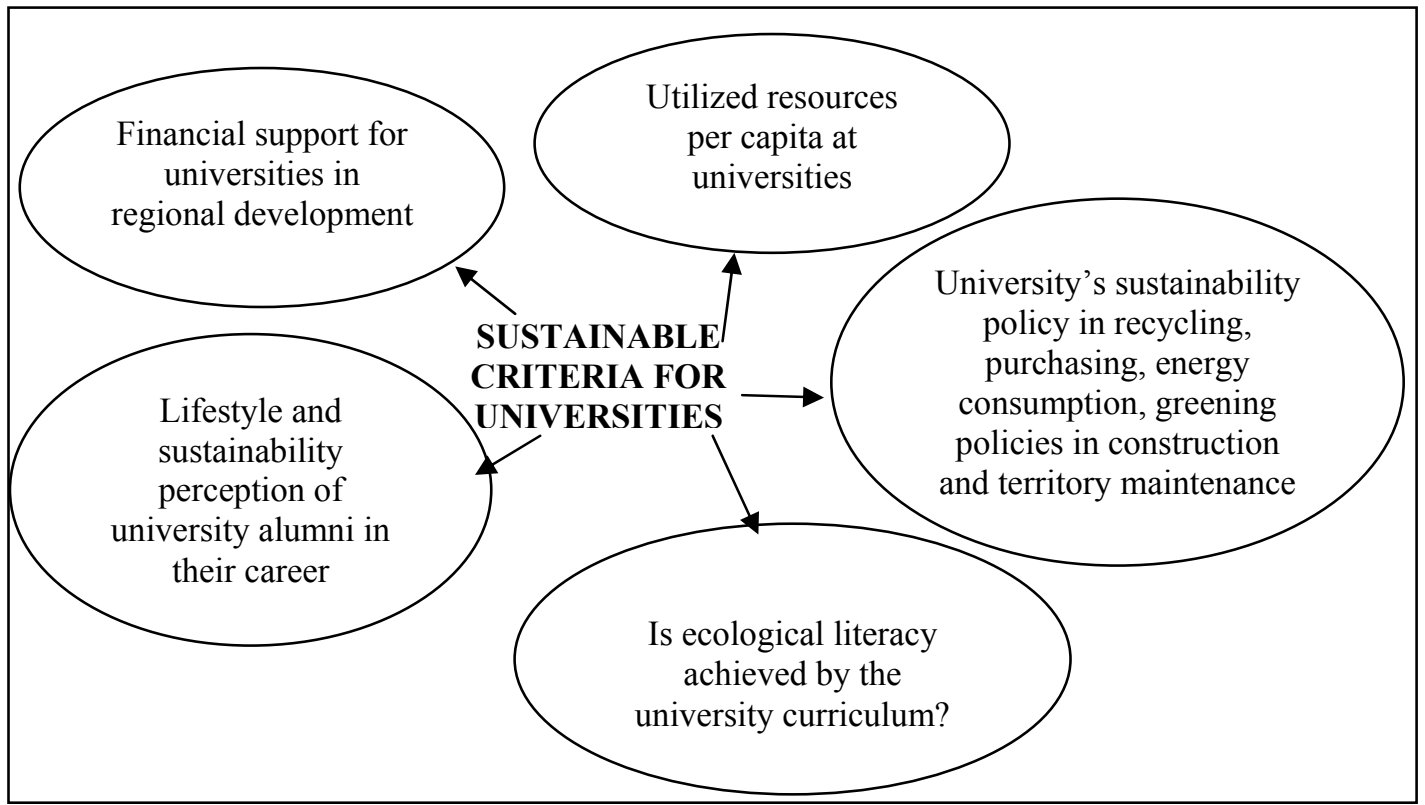

Figure 1. Proposed Criteria for Sustainable Governance of a University

Clugston and Calder (1999) claim that institutions must take action in seven areas to make progress toward sustainability: 1) written mission and purpose statements; 2) academic disciplines, program requirements, and research; 3) the ecological and social contexts of the campus; 4) hiring, tenure and promotion systems; 5) production and consumption patterns; 6) administrative leadership and student life; 7) local and global outreach and partnerships. Therefore, the author of this article proposes criteria for sustainable governance of a university in Figure 1.

Reaching for implementation of set tasks, Filho (2002) outlines six guidelines for promoting sustainability teaching and curriculum design strategies in HE:

1) sustainability should not be seen as a discrete discipline. The introduction of sustainability into the curriculum involves the provision of new skills directed towards;

2) the understanding and achievement of an harmonic 'people-environment-nature' relationship. It is predicated as much on winning 'hearts and minds' as formal instruction;

3) sustainability is not the exclusive preserve of one established discipline. It is part of a shared life and common domain. It is interdisciplinary in its philosophy and focus;

4) there are many and flexible approaches to teaching sustainability. The main pedagogic thrust should be towards raising consciousness;

5) the precepts of sustainability need to be demonstrated. The best way to reach out to people who do not understand sustainability, or who resist the philosophy, is to 
demonstrate its essence and practical application. systematic progress in teaching sustainability cannot be made without changes in the content or focus of curricula;

6 ) it is a myth that only a handful of experts are qualified to engage in sustainability education. Sustainability has universal currency. Indeed, without realising it, many practitioners and university teachers have unwittingly subscribed to its fundamental principles and core values and have practised sustainability.

\section{Reforming Higher Education System with Interdisciplinary Approach in Focus}

The swift demise of the Soviet Union and the eclipse of its hegemony in Central and Eastern Europe (CEE) dramatically heightened appreciation of the vital role of critical thinking among university students and staff and of universities as an important independent voice for societal analysis (Grundey, 2005; Ciegis et al, 2005a; 2005b). General Education's special contribution to encouraging and training the habits of mind, and under-girding the university's role of social criticism appears more needed than ever, especially as academic freedom and free expression in academia seem to be more threatened in the new millennium. The reforms in HE is taking place in all CEE countries, which contributes to the Europisation process of latter HE systems (Grundey, 2004a, 2004b, 2004c). CEE universities have introduced the three-layer HE system, comprising of bachelor, master and $\mathrm{PhD}$ studies, they have established links with scientific research and have started developing partnerships with business entities. Therefore, the goal of qualitative labour force is on mind on every university rector and administrator in order to adhere to market trends and demands.

The recent external expertise and assessment of study programmes in Management and Business Administration at Universities of Lithuania, which was carried out in 20062007, suggested that the number of study programmes in this field has to be considerably reduced, which will be a painful procedure. The final conclusions from this external assessment are not officially announced yet, but from the impression, perceived at Kaunas Faculty of Humanities, Vilnius University (VU KHF), Lithuania, the pivotal contemplation was on the major strength of VU KHF in capability to run interdisciplinary study programmes, such as Business Informatics (Bachelor degree), Lithuanian Language and Advertising (Bachelor degree), Cultural Management (Bachelor degree), Russian and English Languages (Bachelor degree) (Grundey et al, 2004a). The experts encourage more possibilities in uniting three major sciences, which are available at VU KHF - social sciences, the humanities and physical sciences - which leaves an immense space for a better balancing of staff, courses, students' flows and income distribution (Grundey, 2004c). VU KHF has also a good record of merging sciences in $\mathrm{PhD}$ dissertations. The cases of merging scientific research of IT and marketing, IT and economics, IT and languages have become an established tradition rather than a one-off study.

Apart from the functional and structural reforms of HE in CEE countries, the quality of studies and its measurement tools are also in the focus of attention (Grundey, 2003; Grundey et al, 2003; Grundey et al, 2004b). The quality of university studies carries a broad character, embracing the surveying of current university students and alumni, current and potential employers, teaching and administrative staff, consequently determining the current market situation for the demand of qualified employees; forecasting and implementing improvements to up-grade current study programmes. An extensive survey in the quality of university studies was performed at VU KHF in autumn 2003 - winter 2004 for a Master degree study programme in Marketing and Trade Management (Grundey et al, 2003; Grundey et al, 2004b). A constructive discussion with marketing employers and experts ensured the strengthening of the programme curriculum by (a) striking the balance of theoretical and practical courses, (b) inviting a social partner on Board of this master degree 
study programme and (c) sharing the experience of alumni, currently employed in the line of their speciality. By the Decision of the Senate of Vilnius University (came into force in December, 2004), study programmes are being reviewed and assessed on a yearly basis (instead of 2-4 years' basis) at the end of the calendar year, which serves as a good but challenging practice.

\section{National Survey on Sustainable Governance of Universities: The Case of Lithuania}

\subsection{Methodology}

Within the theoretical framework of topic, a national survey was conducted in Lithuania universities to research the sustainability principles as applied in their governance, study curricula and general knowledge on sustainability. This paper presents only partial results of the survey, which was conducted in the second half of 2007 and the first half of 2008 , as indicated in Table 1.

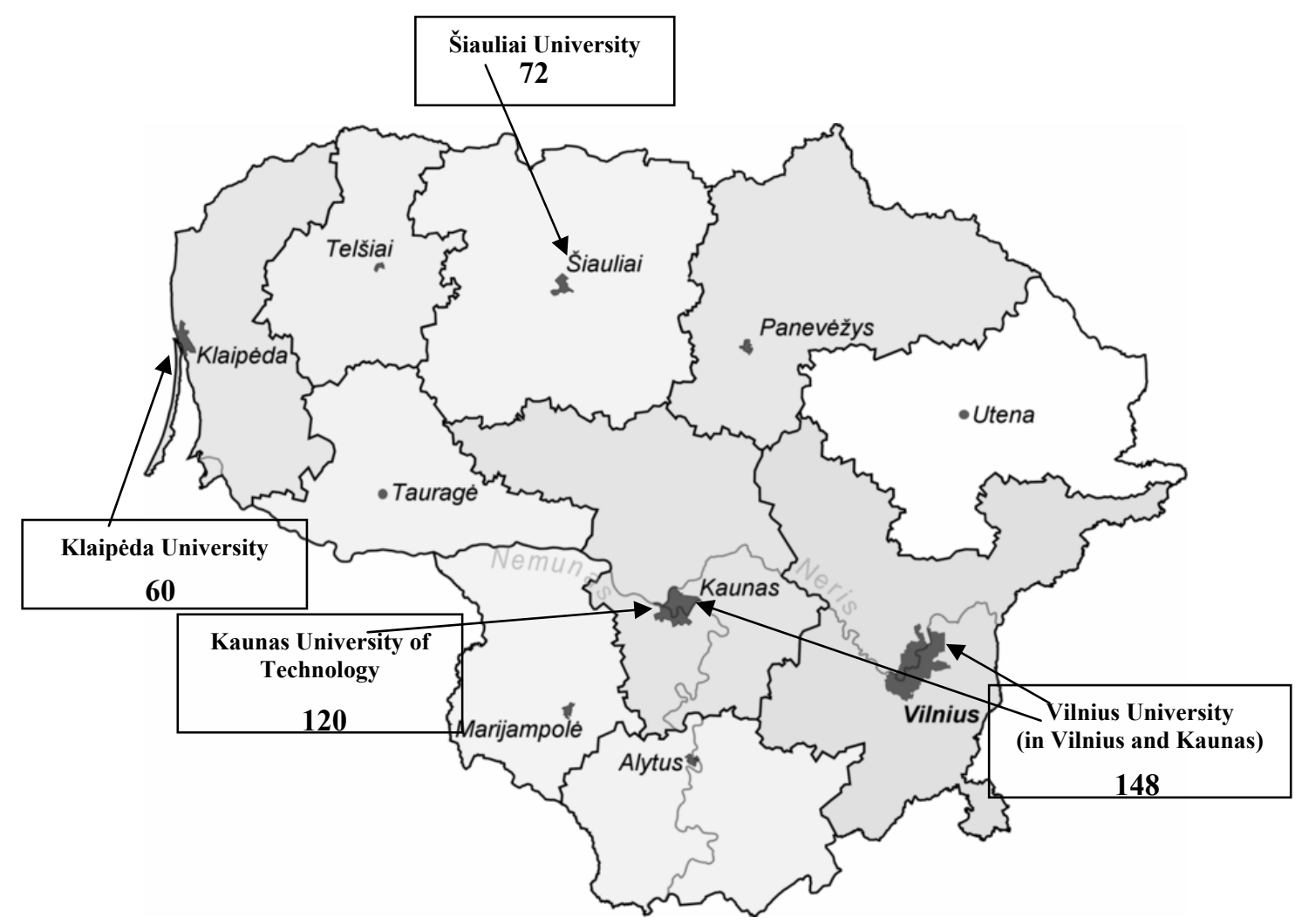

Legend: the four surveyed Lithuanian universities are indicated on the country's map with the number of respondents, who participated in the national survey.

Figure 1. The Geography of Four Surveyed Lithuanian Universities, 2007-2008

The object of the research was students and lecturers of four Lithuanian universities, listed below:

- Vilnius University (VU) (East-Southern Lithuania) - 148 respondents;

- Kaunas University of Technology (KTU) (Central Lithuania) - 120 respondents;

- Šiauliai University (Northern Lithuania) (ŠU -72 respondents;

- Klaipeda University (KU) (Western Lithuania, the Seaside) - 60 respondents.

The selection of the four towns was determined by the fact that they are the biggest towns in the country and they all have universities located in them (Figure 1). 
Table 1. The Survey Scenario and Timetable, 2007-2008

\begin{tabular}{|l|l|l|l|l|l|l|}
\hline \multirow{2}{*}{ Survey stages } & \multicolumn{2}{|c|}{$\mathbf{2 0 0 7}$} & & \multicolumn{2}{c|}{$\mathbf{2 0 0 8}$} \\
\cline { 2 - 6 } & October & November & December & January & February & March \\
\hline $\begin{array}{l}\text { Identification of the research } \\
\text { object and method, sample } \\
\text { selection, preparation of the } \\
\text { questionnaire }\end{array}$ & & & & & \\
\hline $\begin{array}{l}\text { The pilot survey of } 20 \\
\text { respondents }\end{array}$ & & & & & & \\
\hline $\begin{array}{l}\text { Distribution of the } \\
\text { questionnaire }\end{array}$ & & & & & & \\
\hline $\begin{array}{l}\text { Systemisation and analysis } \\
\text { of the primary data }\end{array}$ & & & & & & \\
\hline $\begin{array}{l}\text { Findings and } \\
\text { recommendations }\end{array}$ & & & & & & \\
\hline
\end{tabular}

The questionnaire contained 26 questions, the four of them allotted to the profiling of a respondent. Four questions will be detailed in our findings subchapter.

\subsection{Findings}

The profile of the respondents from the four Lithuanian universities was as follows:

- 226 females and 174 males.

- $105(26 \%)$ respondents represent the age group of 18-20, 137 (34.\%) respondents belong to the age group of 26-30, while $77(19 \%)$ respondents indicated that they are 31 and over.

- $314(78 \%)$ respondents were students and $86(22 \%)$ indicated themselves as lecturers or administrative staff of a university.

As it was earlier mentioned in the paper, sustainable development requires the efforts of all participants of the community, and here, in the survey, universities are perceived as academic communities with their set of rules and behaviours. In the questionnaire, it was important to find out, what could be a potential source of the knowledge on sustainable development.

As it is indicated in Figure 2, the majority of students found out about sustainable development from their university professors (46\%). It is also thought that university professors have a moral imperative to form a positive attitude of their students towards sustainable development. The Internet resources take the second stand (21\%) alongside with scientific and popular literature (19\%). A considerably small number of students discovered about sustainability in press $(10 \%)$ and watching TV programmes $(4 \%)$. It was quite a surprising finding that parents did not play any role in forming students' attitude towards sustainability (Figure 2).

Even though Figure 2 emphases that most respondents indicated that they discovered about sustainability from their university professors, half of the students-respondents (170 or $54 \%$ ) mentioned that they do not have courses related to ecology, environmental protection or sustainable (Figure 3). Among the students, who indicated that their disciplines contain some aspects of sustainability or have full courses on it, 58\% of them study at Vilnius University, Lithuania, which is an important indicator in the research. The least number of students $(3 \%)$ are in contact with sustainability knowledge at the university were from Šiauliai University in the Northern Lithuania (Figure 3). 

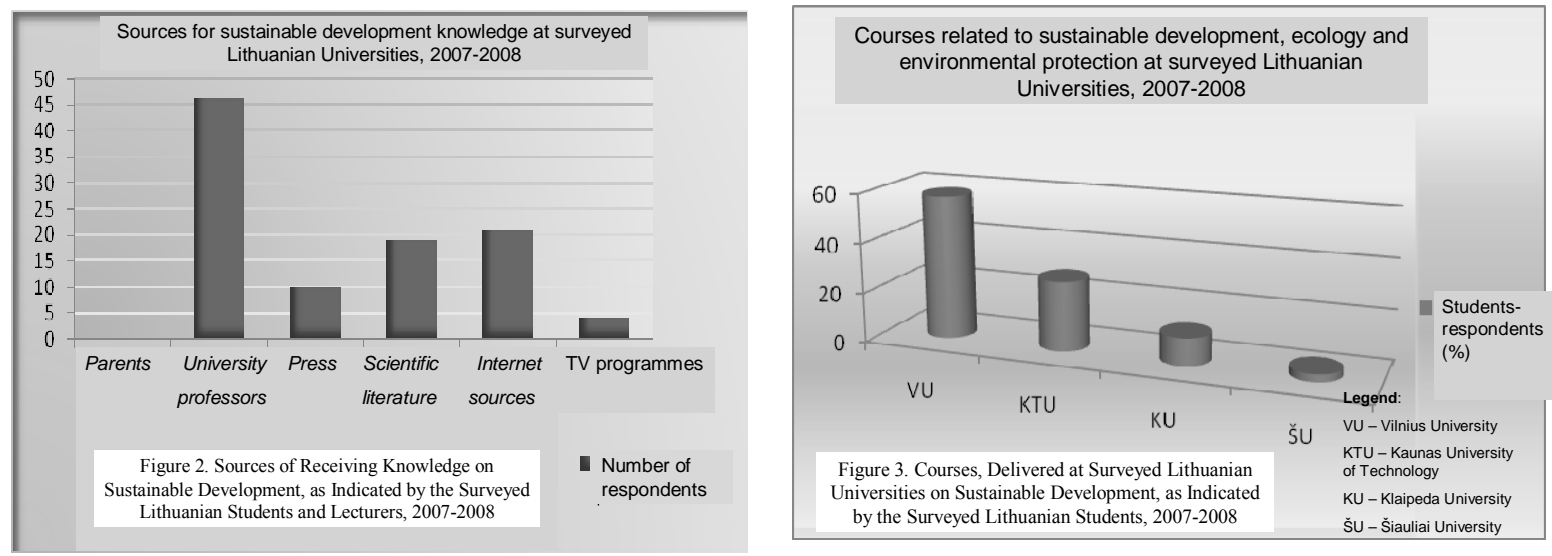

Another focus of the national research on sustainable development in Lithuania was the role of students' unions in the institutions of higher education. It is well known that students' unions are representing their students in a faculty or university as a whole. They perform quite a bunch of functions, e.g., protecting and monitoring the rights and interests of students; participating in the study process by proposing improvements in study programmes and study quality; caring about social well-being of the students; fostering and organizing students' leisure time and cultural life; developing international relations; developing relations with other students' unions in national universities, business partner-institutions and social groups; mediating open and fare academic discussions on sustainable society and judicial state development; adhering to academic and national culture and traditions.
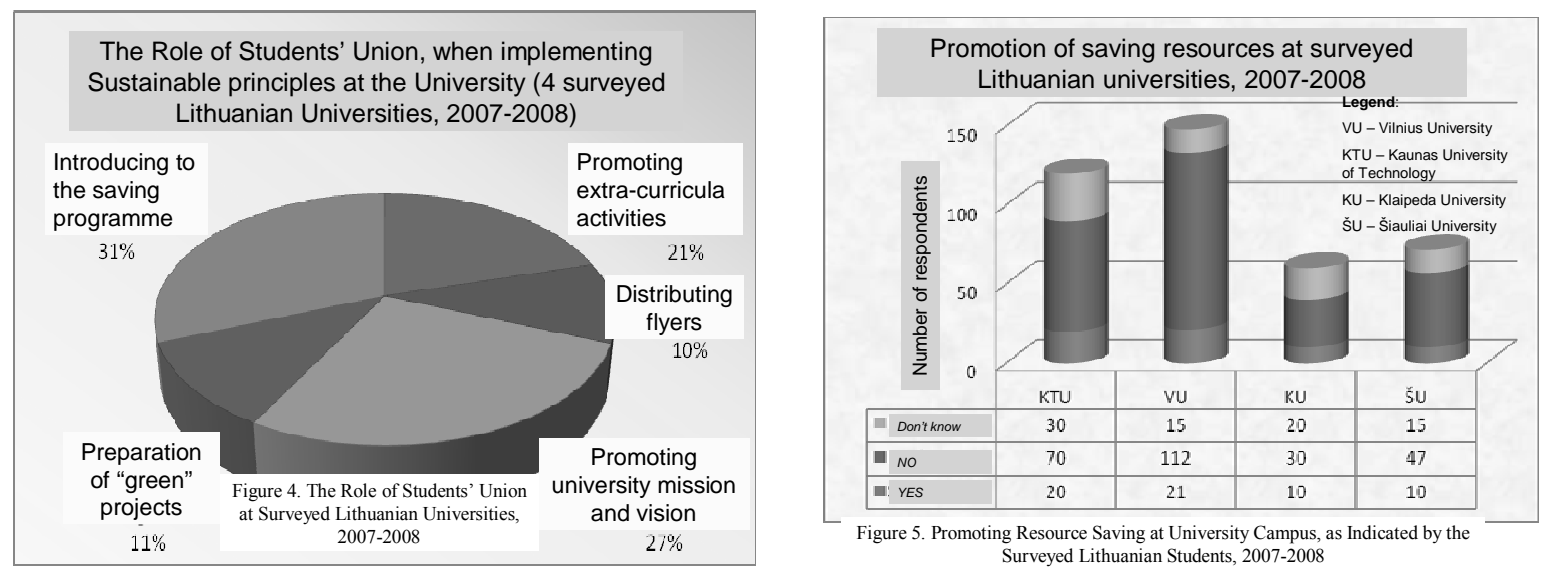

As the Lithuanian survey indicates (Figure 4), a students' union might participate in the process of promoting sustainability ideas in a university campus. First of all, it could introduce the students to the university policies in saving resources, as it was mentioned by $31 \%$ of the respondents (the total of 315 ) in the four surveyed Lithuanian universities. It could be very useful, if students' unions initiated the promotion of university's mission and vision, especially to freshmen (27\% of respondents), as indicated by Scott (2004). It was suggested by the respondents that students' unions could initiate extra-curricula activities $(21 \%)$ for fostering sustainable development and resource saving programmes. According to the opinion of the respondents, students' unions should also participate and coordinate the "green" projects on campus or in the town (113 respondents), as well as be the distributors of flyers on this topic on campus (105 respondents).

The majority of Lithuanian respondents (65\%) suggested that university administration and teaching staff failed to encourage the university community to save 
resources. A positive reply was received only from $15 \%$ of the survey participants. As Figure 5 indicates, students from Vilnius University and Kaunas University of Technology are mostly encouraged to save natural resources. As the proportion of participants from these two Lithuanian universities was considerably higher, the negative answer ("No") was also a dominant in these universities. Nevertheless, the students from remaining two Lithuanian universities - Klaipeda University and Šiauliai University - also opted for a negative answer in reaction towards the resource saving promotion at their university campuses.
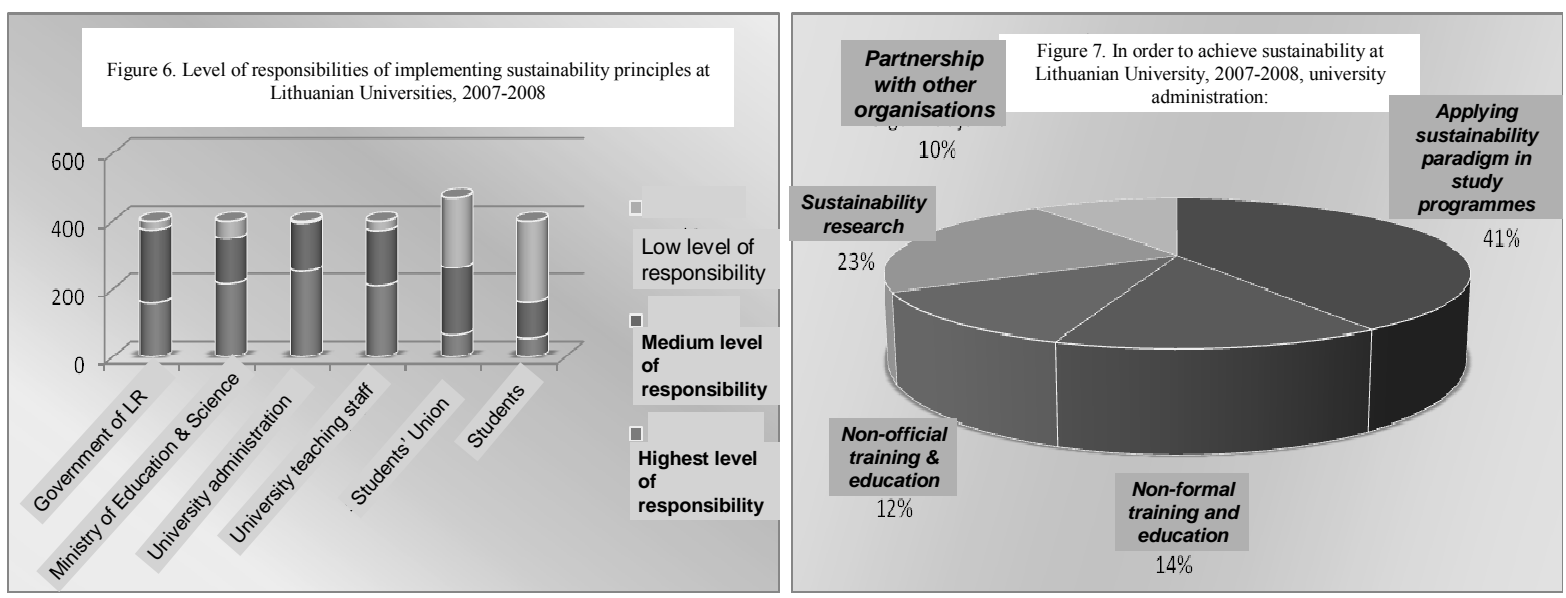

In the survey, the respondents from four Lithuanian universities were asked to rate the level of responsibility (low, medium and the highest), and to indicate, who should be in charge of implementing sustainability principles at universities (Figure 6): the government of the Republic of Lithuania; the Ministry of Education and Science; university administration; university teaching staff or students themselves. As presented in Figure 6, the respondents ( $75 \%$ of students and $31 \%$ of university lecturers) indicated that the highest burden of responsibility lies on the shoulders on:

1) university administration;

2) the Ministry of Education and Science;

3) university teaching staff.

It was an interesting finding that students do not see themselves as being highly involved in the promotion of sustainability principles at the university and certainly they do not perceive that it should be their mission of any kind.

As university administration came first in being responsible for implementing sustainability principles in an individual university, the administrative personnel should unite their efforts in educating the university community in non-formal (14\%) and non-official $(12 \%)$ way raising sustainability awareness. According to the respondents, the highest probability in achieving success in applying sustainable principles of university governance is by:

a) participating in projects, related to environmental protection, sustainable development and ecology (23\%);

b) including courses on sustainable development into the study curricula or cover this subject in related disciplines (41\%).

86 university teaching and administrative staff members were questioned on their participation in projects, related to sustainable development at their universities, only $30 \%$ of them defined their activities as distantly related to this subject matter. 


\section{Discussion and Recommendations}

Educators should discuss across disciplines to identify convergence and divergence. They should reflect about how education should prepare people for using their rights and responsibilities in society, education should empower people rather than teach them. Many participants reflected first of all on the role of educators not as the source of knowledge and moral admonition, but as a guide and process facilitator and a learner at the same time. Some participants would like educators to have more knowledge of principles of sustainable development and other content of 'deeper ecology'. Educators should learn that the empowerment of individuals to participate effectively in the process of social change is the key purpose and that the participation relates to direct interventions that will impact on the direction, progress and dynamics of social, economic and environmental development. These interventions will include decisions and actions: as consumers; within their occupations; as employees/employers; as voters (or in other forums of social decision making; within their homes and communities).

Sustainability is a process of ensuring the wise use of all resources within a framework in which environmental, social and economic factors are integrated. The University is committed to placing sustainability at the heart of its mission:

- making sustainability integral to the delivery of research, teaching and operational objectives;

- taking positive actions promoting continual environmental improvement; and

- setting and achieving clearly defined sustainable development objectives and targets.

The national survey in Lithuania amongst four university students and teaching and administrative staff members (i.e., Vilnius University, Kaunas University of Technology, Klaipeda University and Šiauliai University) has demonstrated that sustainability principles have still a long way to be approved and implemented. The perception amongst the respondents dominate that somebody else should take care of the sustainability policy within an orgnisation rather than starting from themselves. In order to design an individual and suitable sustainability policy at the university, the following guidelines and recommendations should be considered.

The University seeks to build on its Environmental Policy and undertakes the following six actions to:

1. Make sustainability a corporate priority:

- encourage students and staff to incorporate informed sustainability perspectives within their work;

- develop the capacities of academic staff to promote understanding of the principles and practice of sustainability;

- establish a corporate culture which seek to embed sustainability in all aspects of the university;

- recognise, celebrate and reward achievement in order to promote the university as a sustainable organisation.

2. Develop and deliver appropriate teaching and research:

- expose all students to the concepts of social, environmental and ethical stewardship;

- encourage students to consider sustainable issues in their academic work in order that they will become active advocates of sustainable development; and

- support and encourage interdisciplinary research into issues of sustainable development.

3. Take a leadership role in sustainability:

- set best practice standards, meet or surpass requirements of environmental legislation and commit to a process of continual environmental improvement; 
- promote awareness, both within the university's and the wider community, of all legislative, economic, technical and market developments that assist progress towards sustainability;

- establish a university audit group to oversee implementation of this policy and associated programmes; and

- encourage and actively support the work of the Environmental Action Group.

4. Contribute to stable community building:

- build partnerships and create local information and learning networks for sharing experiences and knowledge of sustainability issues with all stakeholders;

- operate in ways that maximise social and economic benefit while minimising any adverse impacts to the local community; and

- invest in staff development, value stakeholder involvement and promote social inclusion and equity.

5. Maintain and develop the University in a sustainable manner:

- promote continual improvement in maintenance practices and establish sustainability guidelines for internal and external design teams and contractors working on new build and refurbishment projects;

- develop procurement procedures with all elements of the supply chain to ensure social, ethical and environmental criteria are integrated into programmes aimed at achieving best value;

- develop accounting procedures which articulate clearly the benefits of sustainable development;

- maximise the efficient use of energy and materials, continually improve pollution prevention measures and increase use of renewable resources;

- minimise waste generation in research and teaching activity and encourage repair, reuse and recycling ahead of the responsible disposal of surplus materials;

- promote practical measures to reduce the impact of travel to and between university sites; and

- establish systems to facilitate data capture for benchmarking.

6. Monitor and report on progress towards sustainability:

- manage responsibly the social, environmental and economic impacts of all university policies and practices and assess potential improvements within the university's decision-making processes;

- conduct reviews of all university policies, management performance standards and operations against internal sustainability targets and best practice standards;

- make the results of social, environmental and sustainability audits and impact assessments carried out by or for the university available to all stakeholders; and

- overall monitoring of this policy will be the responsibility of the university's audit group for sustainability. 


\section{References}

1. Ciegis, R., Grundey, D. (2005b). „Economic Competition and the Sustainability Paradigm: Concepts of Strong Comparability and Commensurability versus Concepts of Strong and Weak Sustainability“. In T. Bernat (ed.). Economic Development and Competition. -Szczecin: Univesity of Szczecin (Poland). - pp. 77-112.

2. Ciegis, R., Streimikiene, D., Grundey, D. (2005a). „Applying the Sustainability Paradigm in Higher Education: Merging Research and Pedagogy“. In Danuta Kopycinska (ed.) Market economy, competition and competitiveness (Economics \& Competition Policy, No 1). Monograph. -Szczecin: University of Szczecin (Poland). -pp. 125-135.

3. Clugston, R. M., \& Calder, W. (1999). Critical Dimensions of Sustainability in Higher Education. In W. Leal Filho (Ed.), Sustainability and university life. Frankfurt am Main u.a.: Lang.

4. Filho, Walter Leal (2002). Teaching Sustainability: Some Current and Future Perspectives. In: (W. Leal Filho, editor) Teaching Sustainability at Universities. Environmental Education, Communication and Sustainability Volume 11. Peter Lang, Frankfurt. pp. 15-23.

5. Grundey D. (2003). The Issue of Education Quality in Universities: Assessing a Master Degree Program of Social Sciences in a Lithuanian University. In Integration of Market Economy Countries: Problems and Prospects. -Riga: Higher School of Economics and Culture, p. 244-257.

6. Grundey, D. (2004a). Lithuania: Reforming Higher Education System. Dedicated to the $425^{\text {th }}$ Anniversary of Vilnius University (1579), Lithuania. - Amsterdam: EAIE (European Association of International Education) Forum, Fall, p. 50-51.

7. Grundey, D. (2004b). "Reforming Higher Education in Lithuania: 1990-200 and Beyond. Dedicated to the 425th Anniversary of Vilnius University (1579), Lithuania", EUROGLOB-A Review of Centre for International Studies and Relations, No 4, Year IV, p. 49-62.

8. Grundey, D. (2004c). Social Sciences and the Humanities in Lithuania: A Break-Through Strategy for a Knowledge-Based Society. In The Development of Economy: Theory and Practice. -Kaunas: VU KHF, p.1-4.

9. Grundey, D. (2005). „Mass Education vs. Interdisciplinary Education from the CrossCultural Perspective“. In Danuta Kopycinska (ed.) Market economy, competition and competitiveness (Economics \& Competition Policy, No 1). Monograph. -Szczecin: University of Szczecin (Poland). -pp. 113-123.

10. Grundey, D., Gregorauskaite, J., Maciute, G. (2003). Implementing Quality in Higher Education: Quality Assessment and Assurance in a Lithuanian University. In Society and Consumption: Economic-Managerial and Social-Cultural Factors. - Kaunas: VU KHF, p. 237-256.

11. Grundey, D., Šavriņa, B., Kanapickienè, R. (2007). „Applying the Principles of Sustainability in University Management: A Comparative Analysis“, Transformations in Business \& Economics, Vol. 6, No 2(12), pp. 67-86.

12. Grundey, D., Toluba, B., Verbauskienè, L. (2004b). Measuring Study Quality at Universities as a Prerequisite for Study Programme Accreditation. In Business and Economic Development in Central and Eastern Europe. -Brno: Brno University of Technology, p. 22-32.

13. Grundey, D., Verbauskienè, L., Toluba B. (2004a). Business Education at Universities: An International Comparative Survey of Interdisciplinary Programmes. In Business and Economic Development in Central and Eastern Europe. -Brno: Brno University of Technology, p.11-21. 
14. Grundey, D., Verbauskienè, L., Toluba, B. (2004c). The Concept of Training in Cultural-Educational Context of Business Studies. In New Trends in the Development of Industry. -Brno: Faculty of Business and Management, Brno University of Technology, p. 27-37.

15. Kooten, G. Van and Bulte E. (2000). The Economics of Nature. Blackwell Publishers. USA-UK.

16. Rowe, Debra (2002). Environmental literacy and sustainability as core requirements: success stories and models. In: Leal Filho, W. (editor). Teaching Sustainability at Universities. Environmental Education, Communication and Sustainability, Volume 11. Peter Lang, Frankfurt.

17. Scott, C. (2004). Regulation in the Age of Governance: the Rise of the Post-Regulatory State, The Politics of Regulation: Institutions and Regulatory Reforms in an Age of Governance. Cheltenham: Edward.

18. Viederman, S. (2003). "Can the Universities Contribute to Sustainability?" Paper presented at the Education for Sustainable Development, October $23 \& 24,2003$, Wannalancit Mills Conference Room.

19. Weick, K. (1976). "Educational organizations as loosely coupled systems", Administrative Science Quarterly, Vol. 21, pp. 1-19. 